\title{
Development of $\mathrm{SnO}_{2}$-based Gas Sensors for Detection of Volatile Organic Compounds
}

\author{
Member Masahiro Kadosaki \\ Non-Member Shigekazu Yamazaki \\ Member Satoshi Fujiki \\ Member Katsumi Tanino \\ Non-Member Chiei Tatsuyama
}

\author{
(Toyama Industrial Technology Center) \\ (Toyama Industrial Technology Center) \\ (Toyama Industrial Technology Center) \\ (Toyama Industrial Technology Center) \\ (Toyama University)
}

Keyword: gas sensor, oxide semiconductor, volatile organic compounds, sick-house syndrome, formaldehyde

\section{Summary}

Recently, sick-house syndrome receive much public attention as a problem of indoor environment. Volatile organic compounds (VOCs) such as formaldehyde (HCHO) and xylene $\left(\mathrm{C}_{6} \mathrm{H}_{4}\left(\mathrm{CH}_{3}\right)_{2}\right)$ generated from building materials are pointed out as one of origins of sick-house syndrome. In the present work, in order to develop a semiconductor type VOC sensor, first of all, the sensitivities of several oxide semiconductor materials were studied. Among the 23 metals oxides examined, the highest sensitivity to HCHO was achieved by $\mathrm{SnO}_{2}$. Further, the sensing property of an $\mathrm{SnO}_{2}$ sensor to $100 \mathrm{ppm} \mathrm{HCHO}$ was extremely improved by addition of 3 wt $\%$ $\mathrm{Ag}$ at $300^{\circ} \mathrm{C}$, but the sensor had a short lifetime. In order to explore another additives, VOC sensing properties of $\mathrm{SnO}_{2} \mathrm{loaded}$ with several metal oxides were investigated. Among the elements loaded ( $5 \mathrm{wt} \%$ ) with each of 14 metal oxides, the $\mathrm{Mn}_{2} \mathrm{O}_{3}$-loaded one was outstanding in sensitivity to $\mathrm{HCHO}$ at $200^{\circ} \mathrm{C}$. However, its sensitivity of the doubly promoted sensor, $\mathrm{Ag}(1 \mathrm{wt} \%)-\mathrm{Mn}_{2} \mathrm{O}_{3}(5 \mathrm{wt} \%)$ $-\mathrm{SnO}_{2}$ to $\mathrm{HCHO}$ was lower than that of each sensor loaded with one additive.

\section{Introduction}

The number of persons injured by indoor-air pollutants, especially in the new residential building, are increasing in recent years. The phenomenon is the so-called sick house syndrome or sick building syndrome $[1,2]$. It is mostly caused by volatile organic compounds (VOCs) emission such as formaldehyde ( $\mathrm{HCHO})$ and xylene $\left(\mathrm{C}_{6} \mathrm{H}_{4}\left(\mathrm{CH}_{3}\right)_{2}\right)$ and toluene $\left(\mathrm{C}_{6} \mathrm{H}_{5} \mathrm{CH}_{3}\right)$ included in adhesives or paints used for residential buildings. The resin adhesives for woods particularly need $\mathrm{HCHO}$ in spite of hazardous substance. However, the hazardous property of HCHO is strongly pointed out lately and WHO (World Health Organization) established the upper limit of HCHO concentration in the room to $0.08 \mathrm{ppm}$.

Over the past decade, many studies have been made on sensors concerning air pollution gases such as $\mathrm{NOx}, \mathrm{SOx}, \mathrm{O}_{3}$, $\mathrm{NH}_{3}$ and indoor-air pollution gases such as $\mathrm{CO}_{2}, \mathrm{CO}$. Very few studies of gas sensors for detection of VOCs in new houses, however, have been reported so far. Therefore, the development of a sensor system available to measure the indoor-air pollution level at high sensitivity is highly desired. In order to detect VOCs in new houses easily and with low cost, we have studied oxide semiconductor type gas sensors. In our previous studies, we found that $\mathrm{SnO}_{2}, \mathrm{In}_{2} \mathrm{O}_{3}, \mathrm{WO}_{3}, \mathrm{ZnO}, \mathrm{Cr}_{2} \mathrm{O}_{3}, \mathrm{Co}_{3} \mathrm{O}_{4}$ showed relatively high sensitivity to $\mathrm{HCHO}, \mathrm{C}_{6} \mathrm{H}_{4}\left(\mathrm{CH}_{3}\right)_{2}$, and $\left(\mathrm{C}_{6} \mathrm{H}_{3} \mathrm{CH}_{3}\right) . \mathrm{SnO}_{2}$ exhibits excellent sensitivity to $\mathrm{HCHO}$, and $\mathrm{WO}_{3}$ shows the highest sensitivity to $\mathrm{C}_{2} \mathrm{H}_{4}\left(\mathrm{CH}_{3}\right)_{2}$ [3].

This paper deals with the $\mathrm{HCHO}$ and $\mathrm{C}_{2} \mathrm{H}_{4}\left(\mathrm{CH}_{3}\right)_{2}$ sensing properties of $\mathrm{SnO}_{2}$ elements loaded with noble metals and various metal oxides, especially $\mathrm{Ag}$ and $\mathrm{MnO}_{2}$.

\section{Experimental}

The commercial powders (Kojundo Chemical Laboratory Co., Ltd.) of metal oxides and noble metals were used for sensor materials and additives, respectively. Several kind of metal oxides were also used for additives. All powders had an average grain size of a few $\mu \mathrm{m}$. The sensor films of various metal oxides used throughout experiment were fabricated on a $96 \%$ alumina substrate with dimension of $12 \times 12 \times 0.6 \mathrm{~mm}^{3}$ by screen printing with 250 mesh.

First, to make the sensor pastes, each metal oxide powder was adequately mixed with organic binder (Tanaka Kikinzoku Kogyo K.K.), which mainly includes ethyl cellulose. Also, $\mathrm{SnO}_{2}$ powder was mixed well with one of 7 noble metal powders or one of 14 metal oxide powders and with organic binder. Next, a pair of parallel Pt film (Tanaka Kikinzoku Kogyo K.K.) electrodes (distance : $0.5 \mathrm{~mm}$ ) was printed on alumina substrates and dried at $100^{\circ} \mathrm{C}$, and then a Pt film heater was printed on the back surface of the substrate and dried at $100{ }^{\circ} \mathrm{C}$, followed by calcination at $900^{\circ} \mathrm{C}$ for $1 \mathrm{~h}$ in air. And then, the sensor paste was screen printed on the alumina substrate and calcined at 600 ${ }^{\circ} \mathrm{C}$ for $1 \mathrm{~h}$ in air. The thickness of the sensor was about $30 \mu \mathrm{m}$ after the calcination.

The sensitivity of the sensor to $\mathrm{HCHO}$ and $\mathrm{C}_{6} \mathrm{H}_{4}\left(\mathrm{CH}_{3}\right)_{2}$ gases was measured in a cubic test chamber which had a capacity of 
about 64 liters and was made by transparent vinyl chloride. A ceramic heater and fan were set in the chamber. The heater was used to vaporize reagents (Wako Pure Chemical Industries, Ltd.) for making test gases and the fan was used to stir the gas of various VOCs, The sensitivities of 12 sensors were able to measure at once in this chamber. The sensitivity was defined as the ratio $\mathrm{Ra} / \mathrm{Rg}$ for n-type semiconductor or $\mathrm{Rg} / \mathrm{Ra}$ for $\mathrm{p}$-type semiconductor, in which $\mathrm{Ra}$ and $\mathrm{Rg}$ stand for the electrical resistance in air and in the sample gas, respectively. X-ray diffraction (XRD) measurement was carried out using a Rigaku RAD-A with $\mathrm{Cu}-\mathrm{K} \alpha$ radiation. X-Ray photoelectron spectroscopy (XPS) measurement was carried out using a Shimazu ESCA-1000 spectrometer with Al- K $\alpha$ radiation (1.486 keV). Binding energies (BEs) were referred to the $A u 4 f 7 n$ level $(84.0 \mathrm{eV})$ of sputtered gold.

\section{Results and Discussion}

\section{3-1 Screening test for base semiconductors}

12 kinds of metal oxides including mainly transition elements were subjected to the screening test for exploring the most sensitive base semiconductor to the 3 kinds of VOCs, HCHO, $\mathrm{C}_{6} \mathrm{H}_{4}\left(\mathrm{CH}_{3}\right)_{2}$, and $\left(\mathrm{C}_{6} \mathrm{H}_{5} \mathrm{CH}_{3}\right)$. The sensitivity of each element was measured for each VOC at $1000 \mathrm{ppm}$ in air. The sensitivities of 18 metal oxides to the 3 kinds of $1000 \mathrm{ppm}$ VOCs at $350^{\circ} \mathrm{C}$ are summarized in Fig. 1. Among the metal oxides examined, the 6 kinds of metal oxides, $\mathrm{SnO}_{3}, \mathrm{In}_{2} \mathrm{O}_{3}, \mathrm{WO}_{3}$, $\mathrm{ZnO}$ (n-type), and $\mathrm{Cr}_{2} \mathrm{O}_{3}, \mathrm{Co}_{3} \mathrm{O}_{4}$ (p-type) show relatively high sensitivity, as seen in the figure.

The sensitivities of these 6 kinds of metal oxides were further investigated in detail for $\mathrm{HCHO}$ and $\mathrm{C}_{6} \mathrm{H}_{4}\left(\mathrm{CH}_{3}\right)_{2}$. Figure 2 shows the sensitivities of 6 kinds of sensors depending on $\mathrm{HCHO}$ concentration ranging 2.5-1000 ppm. $\mathrm{HCHO}$ could be detected with the excellent sensitivity by both $\mathrm{SnO}_{2}$ and $\mathrm{In}_{2} \mathrm{O}_{3}$. Similarly, Fig. 3 shows the dependence of the sensitivities of

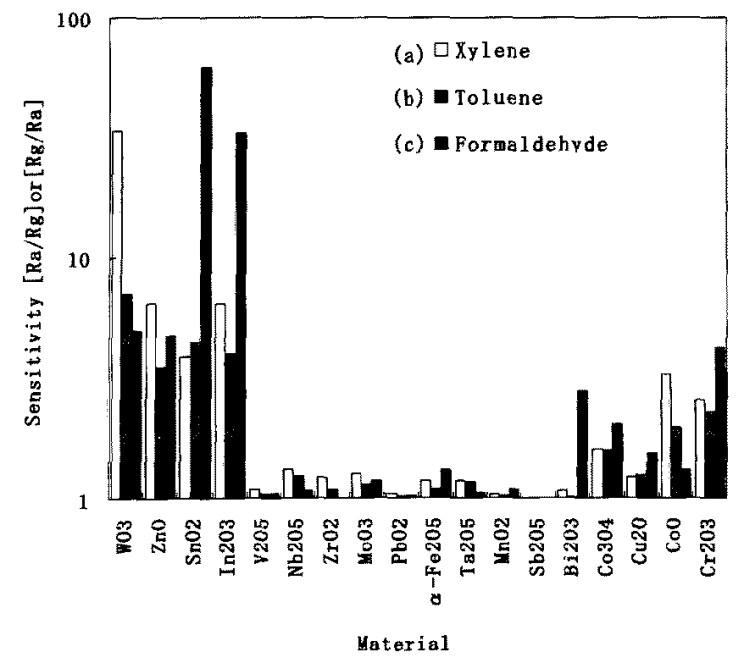

Fig.1. Sensitivities of various oxide semiconductor materials to three VOC gases, (a)xylene, (b) toluene and (a) formaldehyde. these sensors on concentration of $\mathrm{C}_{6} \mathrm{H}_{4}\left(\mathrm{CH}_{3}\right)_{2}$. Xylene was detected with the highest sensitivity by $\mathrm{WO}_{3}$. For both of Figs. 2 and 3 , a good linearity isn't obtained in the log-log plot of the sensitivity and concentration. However, the detectable limits to HCHO could be roughly estimated about $1 \mathrm{ppm}$ by $\mathrm{SnO}_{2}$ or $\mathrm{In}_{2} \mathrm{O}_{3}$, as seen in Fig. 2, and that to $\mathrm{C}_{6} \mathrm{H}_{4}\left(\mathrm{CH}_{3}\right)_{2}$ could be estimated about a few ppm by $\mathrm{WO}_{3}$, as shown in Fig. 3. From a practical viewpoint, these sensors should be sensitive enough to sub-ppm VOCs (HCHO etc) because concentrations of various VOCs are generally $0.1 \mathrm{ppm}$ or less in a new house.

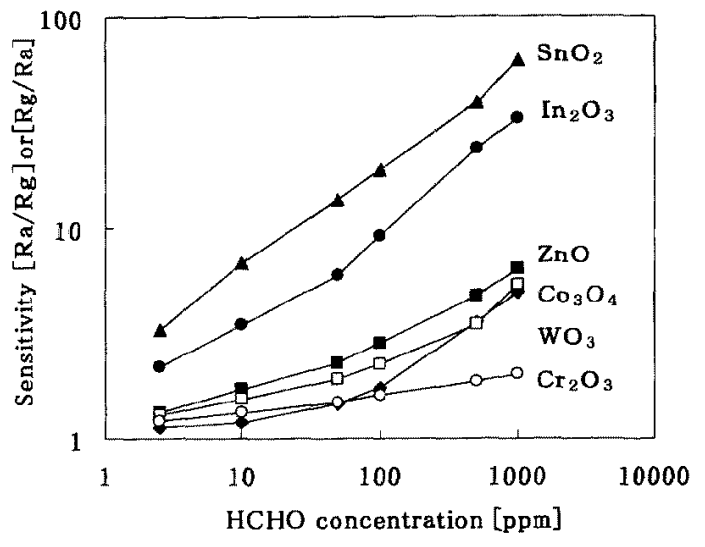

Fig.2. Dependence of sensitivities of selected sensors operated at $350^{\circ} \mathrm{C}$ on concentration of formaldehyde gas.

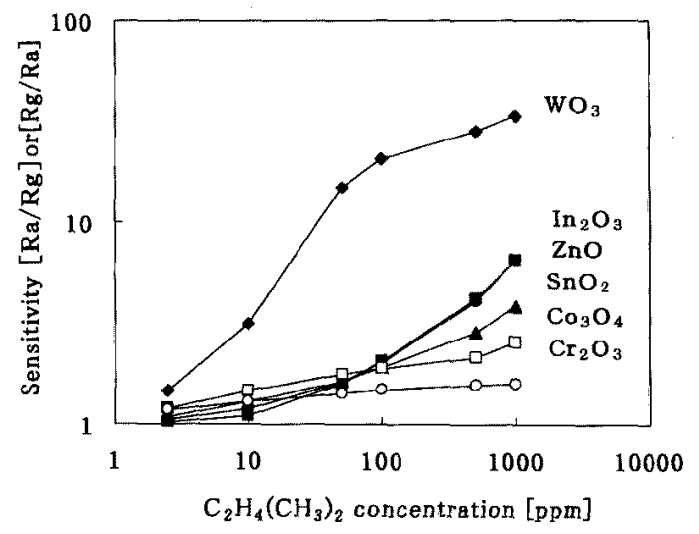

Fig.3. Dependence of sensitivities of selected sensors operated at $350^{\circ} \mathrm{C}$ on concentration of xylene gas.

\section{3-2 Sensing properties of $\mathrm{SnO}_{2}$ sensors loaded with noble metals}

One of the purpose of our study is to develop the sensor which is capable of detecting $0.01 \mathrm{ppm} \mathrm{HCHO}$. Generally, as the means of sensitization, the grain-size control, valency control, addition of another material (chemical or electronic sensitization ) and sensor configuration are well known [4-6]. The present work is intended as an investigation of promoting effect of noble metals and metal oxides.

Figure 4 shows the sensitivities of $\mathrm{SnO}_{2}$-based sensors loaded 


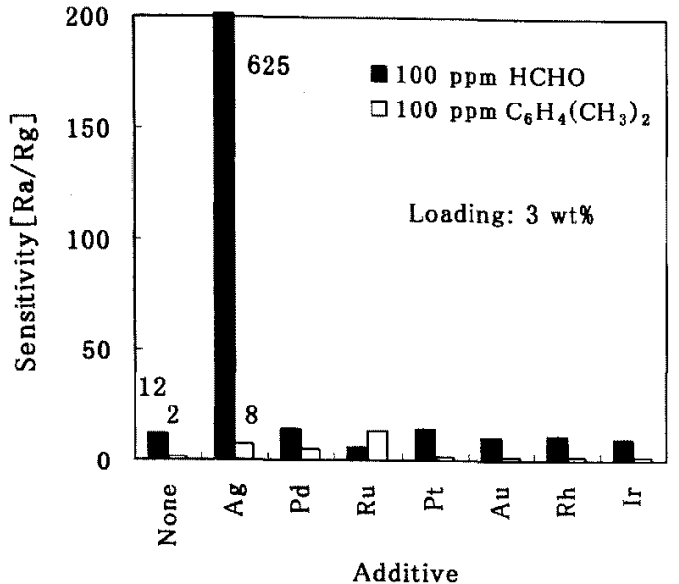

Fig.4. Sensitivities to formaldehyde ( $\square$ ) and xylene $(\square)$ of $\mathrm{SnO}_{2}$ based sensors loaded with various noble metals (3 $\mathrm{wt} \%$ ) operated at $300^{\circ} \mathrm{C}$.

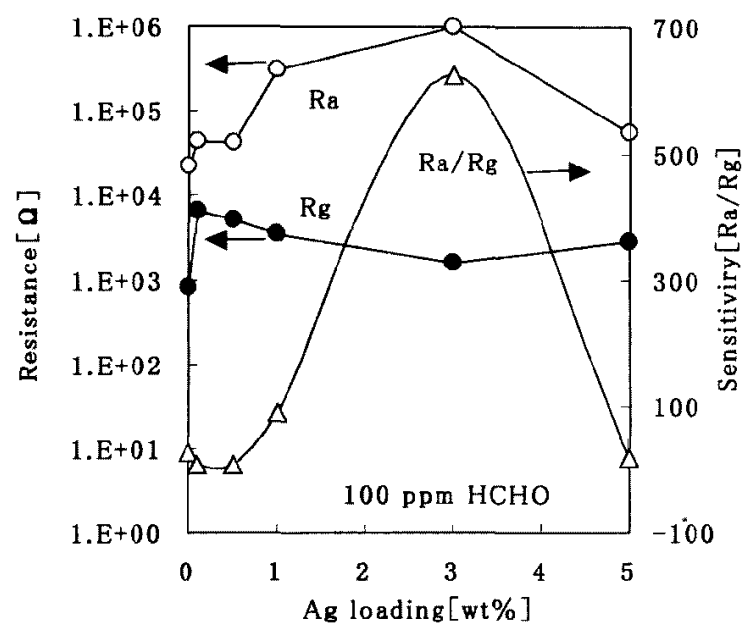

Fig.5. Effects of $\mathrm{Ag}$ loading on electrical resistances in air (Ra) and in $100 \mathrm{ppm} \mathrm{HCHO}(\mathrm{Rg})$ as well as resulting gas sensitivity $\left(\mathrm{Ra} / \mathrm{Rg}\right.$ ) for $\mathrm{Ag}-\mathrm{SnO}_{2}$ sensors operated at $300^{\circ} \mathrm{C}$.

with 7 kinds of noble metals to $100 \mathrm{ppm} \mathrm{HCHO}$ and $\mathrm{C}_{6} \mathrm{H}_{4}\left(\mathrm{CH}_{3}\right)_{2}$ at $300^{\circ} \mathrm{C}$. It is found that $\mathrm{Ag}$ greatly enhanced the sensitivity of $\mathrm{SnO}_{2}$ to $\mathrm{HCHO}$ as much as about 40 times larger than that without Ag.

Figure 5 shows the electrical resistance in air $(\mathrm{Ra})$ and in $100 \mathrm{ppm} \mathrm{HCHO}(\mathrm{Rg}$ ) as well as the resulting gas sensitivity for each $\mathrm{Ag}-\mathrm{SnO}_{2}$ sensor at $300^{\circ} \mathrm{C}$ as a function of $\mathrm{Ag}$ loading. $\mathrm{Ra}$ increases with increasing $\mathrm{Ag}$ content up to 3 weight percent ( $w 1 \%$ ) and beyond that decreases gradually. On the other hand, at first $\mathrm{Rg}$ increases up to $0.1 \mathrm{wt} \%$ and then decreases with $\mathrm{Ag}$ content up to $3 \mathrm{wt} \%$ and increases again. As a cause of the sensitization, an electronic interaction between $\mathrm{Ag}$ and $\mathrm{SnO}_{2}$ which has been indicated by Yamazoe et al., seems to be concerned [7-8]. That is, in air, an $\mathrm{Ag}$ particle dispersed on
$\mathrm{SnO}_{2}$ surface may be covered by $\mathrm{Ag}_{2} \mathrm{O}$, forms a redox couple of $\mathrm{Ag}^{+} / \mathrm{Ag}^{0}$, the electronic potential of which is located at $5.3 \mathrm{eV}$ below the vacuum level $(0.79 \mathrm{eV}$ vs NHE; NHE potential is located at $4.5 \mathrm{eV}$ below the vacuum level). Also, the electron affinity of $\mathrm{SnO}_{2}$ is taken to be $4.49 \mathrm{eV}$, and the Fermi level $\left(\mathrm{E}_{F}\right)$ of $\mathrm{SnO}_{2}$ is assumed to be $0.1 \sim 0.2 \mathrm{eV}$ below the conduction band, and the work function of $\mathrm{SnO}_{2}$ is thus estimated at $4.59 \sim 4.69 \mathrm{eV}$. Therefore, to attain electronic equilibrium, the migration of electron from the surface of $\mathrm{SnO}_{2}$ to that of $\mathrm{Ag}$ takes place, producing an electron depleted space-charge layer, resulting in the increase of resistance of $\mathrm{SnO}_{2}$. In contrast, in formaldehyde gas which causes the reduction of $\mathrm{Ag}^{+}$to $\mathrm{Ag}^{0}$, the $\mathrm{EF}$ of $\mathrm{SnO}_{2}$ shifts upward to be pinned at the work function of $\mathrm{Ag}(4.49 \mathrm{eV})$, resulting in a decrease of resistance of $\mathrm{SnO}_{2}$. As the electron affinity of $\mathrm{Ag}_{2} \mathrm{O}$ is eventually much stronger than that of the adsorbed oxygen, leading to the much higher gas sensitivity.

Thus, the addition of $\mathrm{Ag}$ particles of about $3 \mathrm{wt} \%$ in $\mathrm{SnO}_{2}$ particles promotes extremely the HCHO sensitivity. However, $\mathrm{Ag}-\mathrm{SnO}_{2}$ sensor had a very short lifetime. The resistance of its sensor began to vibrate up and down in air as if it resonates, and the vibrations of its resistance became more and more large with time. At the present stage, we have no clear explanations for such instability of the resistance. Further investigations are necessary on the $\mathrm{SnO}_{2}$ sensor loaded with $\mathrm{Ag}$.

\section{3-3 Sensing properties of $\mathrm{SnO}_{2}$ sensors loaded with metal oxides}

As we mentioned in the previous section, owing to the instability of $\mathrm{Ag}-\mathrm{SnO}_{2}$ sensor, metal oxides were looked for new modifier instead of Ag. Figure 6 summarizes the sensitivities of $\mathrm{SnO}_{2}$ elements loaded with various metal oxides $(5 \mathrm{wt} \%)$ to $\mathrm{HCHO}$ and $\mathrm{C}_{6} \mathrm{H}_{4}\left(\mathrm{CH}_{3}\right)_{2}$ at $280^{\circ} \mathrm{C}$ and $200^{\circ} \mathrm{C}$. Although most of additives are little effective, the $\mathrm{MnO}_{2}$ ( $5 \mathrm{wt} \%$ ) $-\mathrm{SnO}_{2}$ sensor shows extremely high sensitivity as high as 161 to $100 \mathrm{ppm}$ $\mathrm{HCHO}$ and 97 to $100 \mathrm{ppm} \mathrm{C}_{6} \mathrm{H}_{4}\left(\mathrm{CH}_{3}\right)_{2}$ at $280^{\circ} \mathrm{C}$. Moreover, the sensitivity of the sensor markes as high as 883 to $100 \mathrm{ppm}$ $\mathrm{HCHO}$ at $200^{\circ} \mathrm{C}$, which is about 100 times larger than that $\mathrm{SnO}_{2}$ without $\mathrm{MnO}_{2}$. In contrast, the sensitivity of the sensor shows as low as 16 to 100 ppm $\mathrm{C}_{6} \mathrm{H}_{4}\left(\mathrm{CH}_{3}\right)_{2}$ and largely falls at $200^{\circ} \mathrm{C}$.

Generally, $\mathrm{C}_{6} \mathrm{H}_{4}\left(\mathrm{CH}_{3}\right)_{2}$ and $\mathrm{C}_{6} \mathrm{H}_{5} \mathrm{CH}_{3}$, which are usually used as the solvent of paint, are highly contained in indoor air pollutants in new houses and therefore these gases may interfere with the detection of $\mathrm{HCHO}$ in coexisting gases. According to the present experiment, it is found that the addition of $\mathrm{MnO}_{2}$ to $\mathrm{SnO}_{2}$ markedly promotes the sensitivity to $\mathrm{HCHO}$ at $200^{\circ} \mathrm{C}$ without increasing the sensitivity to $\mathrm{C}_{6} \mathrm{H}_{4}\left(\mathrm{CH}_{3}\right)_{2}$ and $\mathrm{C}_{6} \mathrm{H}_{5} \mathrm{CH}_{3}$.

Figure 7 shows the electrical resistance of $\mathrm{MnO}_{2}-\mathrm{SnO}_{2}$ sensors in air ( $\mathrm{Ra})$ and in $100 \mathrm{ppm} \mathrm{HCHO} \mathrm{(Rg)} \mathrm{as} \mathrm{well} \mathrm{as} \mathrm{the}$ resulting $\mathrm{HCHO}$ sensitivity at $200^{\circ} \mathrm{C}$ as a function of $\mathrm{MnO}_{2}$ loading. Ra increases steeply with an increase in $\mathrm{MnO}_{2}$ loading up to about $5 \mathrm{wt} \%$ and then still increases gradually for more loading. On the other hand, $\mathrm{Rg}$ increases gradually with an increase in $\mathrm{MnO}_{2}$ loading in the range between 0 and $20 \mathrm{wt} \%$. 

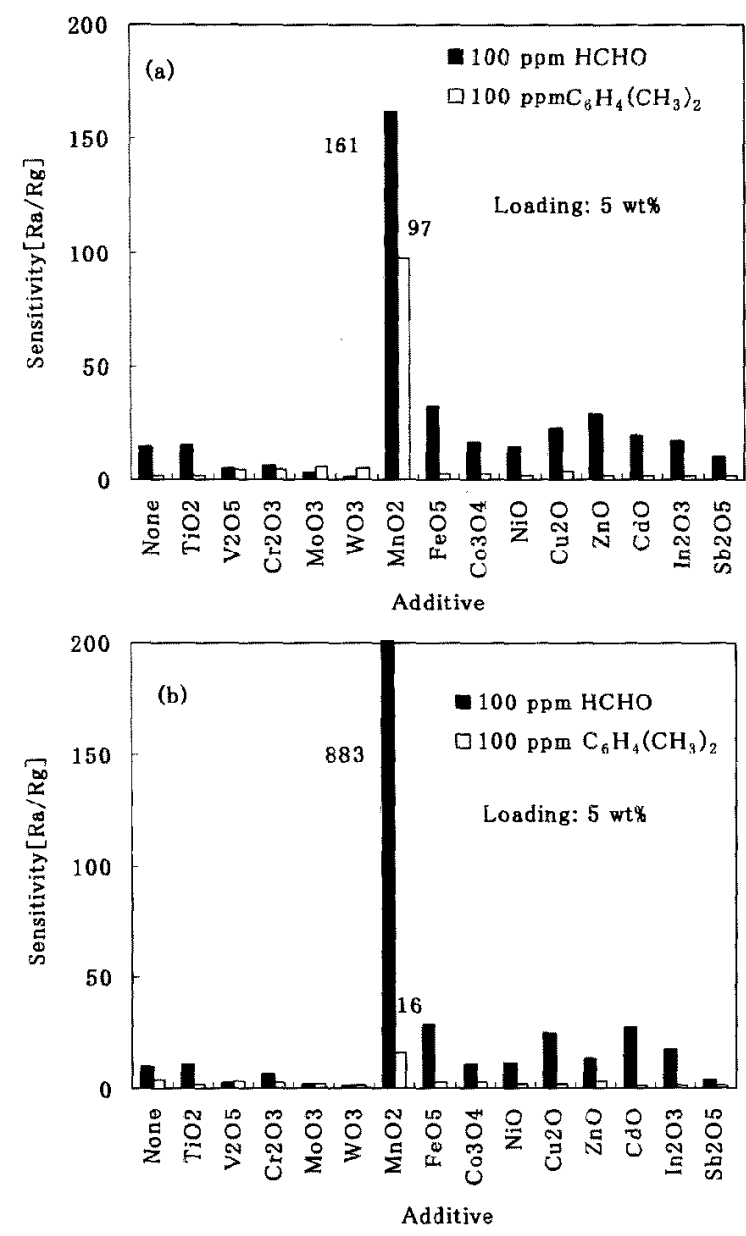

Fig.6. Sensitivity of $\mathrm{SnO}_{2}$-based sensors with various additives to $100 \mathrm{ppm} \mathrm{HCHO}$ and $100 \mathrm{ppm}_{6} \mathrm{H}_{4}\left(\mathrm{CH}_{3}\right)_{2}$ at (a) $280^{\circ} \mathrm{C}$ and (b) $200^{\circ} \mathrm{C}$.

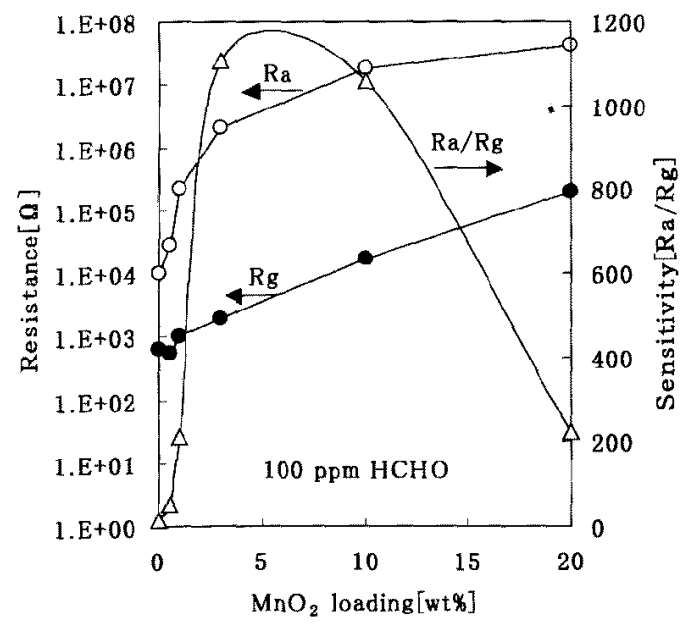

Fig.7. Effects of $\mathrm{MnO}_{2}$ loading on the electrical resistances (Ra) in air and in $100 \mathrm{ppm}$ HCHO $(\mathrm{Rg})$ as well as resulting gas sensitivity $\left(\mathrm{Ra} / \mathrm{Rg}\right.$ ) for $\mathrm{MnO}_{2}-\mathrm{SnO}_{2}$ sensors at $200^{\circ} \mathrm{C}$.
As a result of such behavior of $\mathrm{Ra}$ and $\mathrm{Rg}$, the $\mathrm{HCHO}$ sensitivity reached a maximum value of about 1200 at $5 \mathrm{wt} \% \mathrm{MnO}_{2}$. The $\mathrm{Ra}$ of $\mathrm{MnO}_{2}-\mathrm{SnO}_{2}$ sensors in Fig. 7 tends to increase further after the sensitivity reached a maximum value (about 1200). On the other hand, the Ra of $\mathrm{Ag}-\mathrm{SnO}_{2}$ sensor in Fig. 5 decrease after the sensitivity reaches a maximum value (about 600 ). Since the resistance of $\mathrm{MnO}_{2}$ is larger than that of $\mathrm{SnO}_{2}$, the resistance of $\mathrm{MnO}_{2}-\mathrm{SnO}_{2}$ sensors is likely to increase toward the $\mathrm{MnO}_{2}$ resistance with increasing $\mathrm{MnO}_{2}$ content.

We examined the reason why sensitivity of $\mathrm{SnO}_{2}$ sensor is increased with $\mathrm{MnO}_{2}$ loading. First, XRD pattern was measured to examine the crystalline state of the sensor. Figure 8 shows XRD pattern of $\mathrm{SnO}_{2}$ loaded with $\mathrm{MnO}_{2}$. It is found that $\mathrm{MnO}_{2}$ changed into $\mathrm{Mn}_{2} \mathrm{O}_{3}$ through calcining, and also no other complex oxides are observed except $\mathrm{Mn}_{2} \mathrm{O}_{3}$ and $\mathrm{SnO}_{2}$. Therefore, as for the crystalline state of $\mathrm{Mn}$-oxide, $\mathrm{Mn}_{2} \mathrm{O}_{3}$ is used instead of $\mathrm{MnO}_{2}$ from now on.

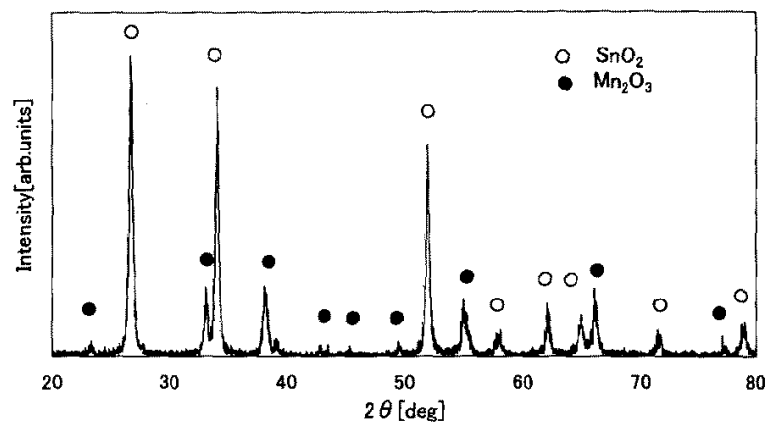

Fig.8. X-ray diffraction patterns for the $\mathrm{MnO}_{2}-\mathrm{SnO}_{2}$ sensors calcined at $600{ }^{\circ} \mathrm{C}$.

Figure 9 shows the sensitivities to $100 \mathrm{ppm} \mathrm{HCHO}$ of $\mathrm{SnO}_{2}$ sensors variously loaded with $\mathrm{Mn}_{2} \mathrm{O}_{3}$ as a function of operating temperature. As shown in the figure, the maximum value of HCHO sensitivity is likely to be obtained in the range between 3 $w t \%$ and $10 w t \%$ loadings. The temperature of maximum sensitivity ( $\mathrm{T}_{\max }$ ) is plotted against $\mathrm{Mn}_{2} \mathrm{O}_{3}$ loading in Fig. 10. The $T_{\max }$ shifts to low operation temperature with an increase in the loading amount. This result indicates that a cause of this sensitization may be related with what is called chemical sensitization [7]. A chemical sensitization is mediated by both activation and spill over effect, and also two types of the chemical sensitization may exist. As for first type, a test gas is activated on the surface of the additives, followed by spillover to the semiconductor surface, and the activated gas react with the surface oxygen, resulting in a decrease in the surface resistance of the n-type semiconductor as an example of $\mathrm{Pt}_{-} \mathrm{SnO}_{2}[7]$. As for second type, the oxygen is activated on the surface of the additive, followed by spillover to the semiconductor surface, leading to increase in activated oxygen for reacting with the test gas in air, resulting in an increase in the surface resistance as an example of $\mathrm{CeO}_{2}-\mathrm{SnO}_{2}$ [9]. The maximum sensitivity of the sensors loaded with additive will be observed at the lower temperatures than that for additive free due to the chemical 
sensitization. It is suspected that a cause of sensitization of $\mathrm{Mn}_{2} \mathrm{O}_{3}-\mathrm{SnO}_{2}$ sensor is the latter because the resistance of $\mathrm{Mn}_{2} \mathrm{O}_{3}-$ $\mathrm{SnO}_{2}$ sensor in air ( $\mathrm{Ra}$ ) increased steeply with an increase in $\mathrm{Mn}_{2} \mathrm{O}_{3}$ loading up to about $10 \mathrm{wt} \%$ in the Fig.7.

$\mathrm{MnO}_{2}\left(\mathrm{Mn}_{2} \mathrm{O}_{3}\right)$ is the high ability material to catalytic oxidation $[10,16]$. So far, it has been pointed out that $\mathrm{MnO}_{2}$ $\left(\mathrm{Mn}_{2} \mathrm{O}_{3}\right)$ tend to activate most of test gas at only the surface of sensor because of its superior oxidation activity [10]. Therefore, in the test gas atmosphere, the resistance of the sensor does not vary much, and the sensitivity as well. On the contrary, in our experiment, $\mathrm{SnO}_{2}$ loaded with $\mathrm{Mn}_{2} \mathrm{O}_{3}$ showed very excellent sensitivity to $\mathrm{HCHO}$.

We suppose the enhancement of the sensitivity achieved by means of $\mathrm{Mn}_{2} \mathrm{O}_{3}$ loading in the present experiment as follows: The size (diameter: about $1 \mu \mathrm{m}$ ) of $\mathrm{Mn}_{2} \mathrm{O}_{3}$ particles used in these sensors are as large as the one of $\mathrm{SnO}_{2}$ particles, hence, the

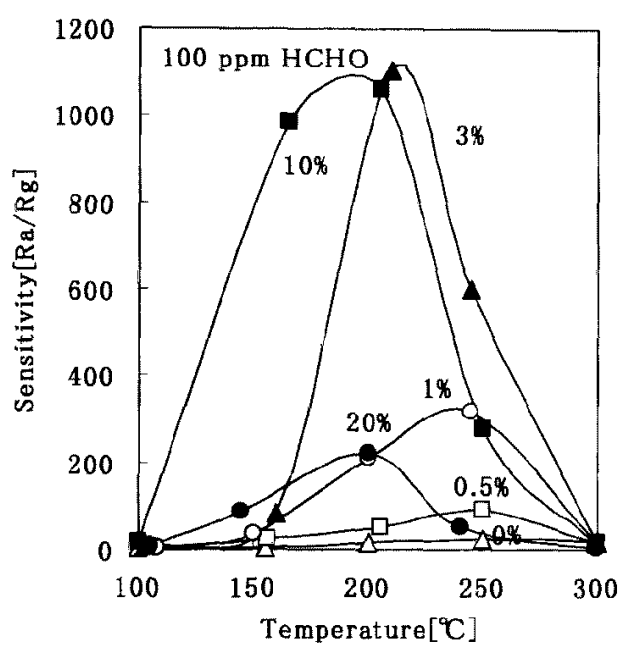

Fig.9. Operation temperature dependence of $100 \mathrm{ppm}$ HCHO sensitivity of $\mathrm{Mn}_{2} \mathrm{O}_{3}-\mathrm{SnO}_{2}$ sensors loaded with various contents of $\mathrm{Mn}_{2} \mathrm{O}_{3}$ (shown in $\mathrm{wt} \%$ ).

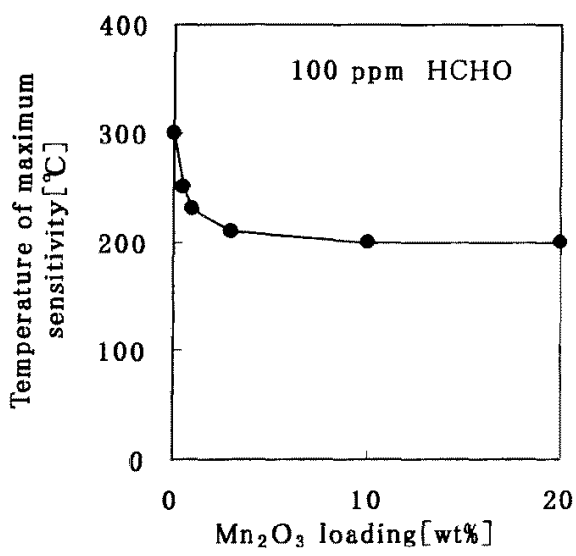

Fig.10. Variation in operation temperature showing maximum sensitivity of $\mathrm{SnO}_{2}$ sensors loaded with different amounts of $\mathrm{Mn}_{2} \mathrm{O}_{3}$ to $100 \mathrm{ppm} \mathrm{HCHO}$. total percent of the surface of $\mathrm{MnO}_{2}$ particles is small compared to that of the usually used $\mathrm{Mn}_{2} \mathrm{O}_{3}$ particles. Consequently, the test gas is oxidized moderately over the whole of sensor, resulting in the great change of the resistance of the sensor, leading to increase of the sensitivity. However, the details of causes should be confirmed in further studies.

\section{3-4 XPS study of $\mathrm{Mn}_{2} \mathrm{O}_{3}-\mathrm{SnO}_{2}$ sensor}

We also suspected that the marked sensitization result from not only the chemical interaction but also the electronic interaction, because the resistance of $\mathrm{Mn}_{2} \mathrm{O}_{3}-\mathrm{SnO}_{2}$ sensor in air increased steeply with an increase in the amount of $\mathrm{Mn}_{2} \mathrm{O}_{3}$ loaded. Furthermore, $\mathrm{Mn}_{2} \mathrm{O}_{3}$ and $\mathrm{SnO}_{2}$ were p-type and n-type semiconductor, respectively. In the past, as for the change of oxidation state of noble metals, such as $\mathrm{Ag}-\mathrm{SnO}_{2}[7,8], \mathrm{Pd}-\mathrm{SnO}_{2}$
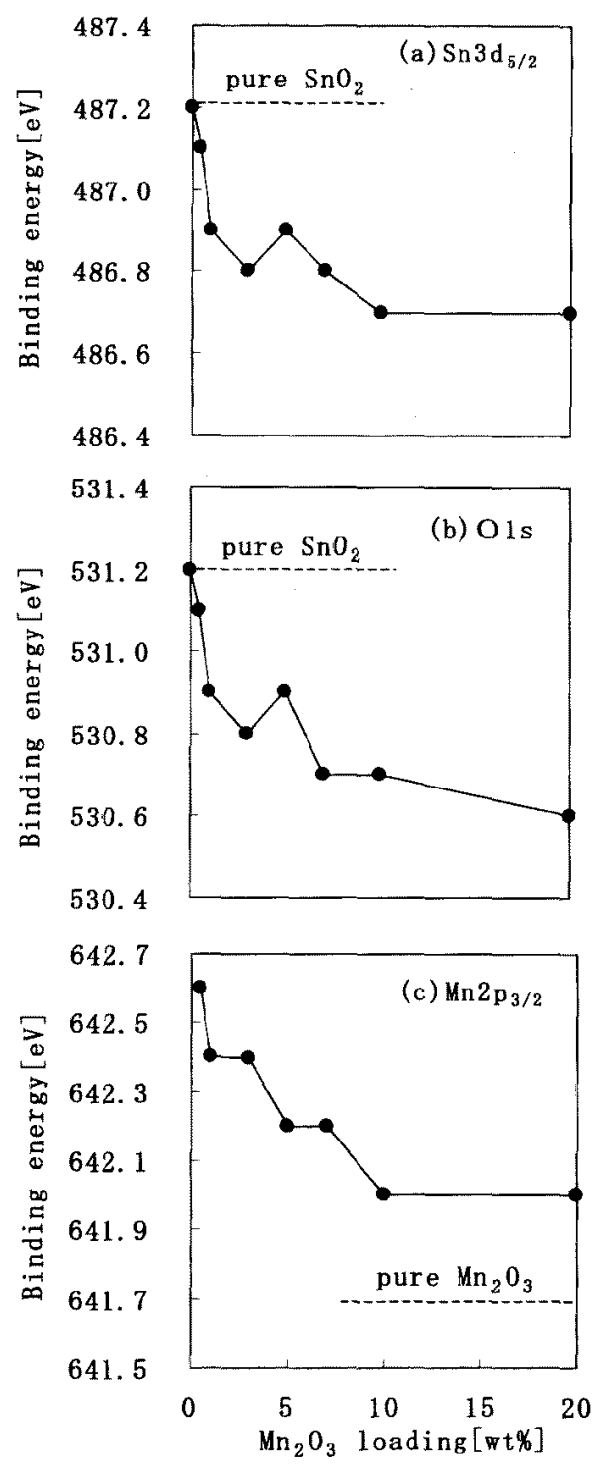

Fig.11. Changes in binding energies of (a) $\mathrm{Sn} 3 \mathrm{~d}_{s / 2}$, (b) $\mathrm{O} 1 \mathrm{~s}$, and (c) $\mathrm{Mn} 2 \mathrm{p}_{32}$ levels for $\mathrm{Mn}_{2} \mathrm{O}_{3}-\mathrm{SnO}_{2}$ as a function of the amount of $\mathrm{Mn}_{2} \mathrm{O}_{3}$. 
[11] and $\mathrm{Au}-\mathrm{WO}_{3}[12]$ systems, were investigated by XPS, and also as for $\mathrm{p}$-n junction type sensors, $\mathrm{CuO}-\mathrm{SnO}_{2}[13,14]$ and $\mathrm{Rb}_{2} \mathrm{CO}_{3}-\mathrm{In}_{2} \mathrm{O}_{3}[15]$ systems were reported. Therefore, we tried to investigate the surface state of the $\mathrm{Mn}_{2} \mathrm{O}_{3}-\mathrm{SnO}_{2}$ system by XPS.

Figure 11 shows the change in the binding energies ( $\mathrm{BEs}$ ) of $\mathrm{Sn} \mathrm{3d}, \mathrm{O}$ 1s and $\mathrm{Mn} \mathrm{2p}$ levels of $\mathrm{Mn}_{2} \mathrm{O}_{3}-\mathrm{SnO}_{2}$ sensors as a function of $\mathrm{Mnz}_{3} \mathrm{O}_{3}$ loading. The $\mathrm{BE}$ value (641.7) of $\mathrm{Mn} 2 \mathrm{p}_{3 / 2}$ of $\mathrm{Mn}_{2} \mathrm{O}_{3}$ was used instead of that of $\mathrm{MnO}_{2}$. As shown in Fig.11, Sn $3 \mathrm{~d}_{s} / 2$ and $\mathrm{O} 1 \mathrm{~s}$ levels shift downward sharply with an increase in $\mathrm{MnO}_{2}$ loading (up to about $10 \mathrm{wt} \%$ ), while the BE of Mn 2p3/2 shifts downward to that of pure $\mathrm{Mn}_{2} \mathrm{O}_{3}$, These $\mathrm{BE}$ shifts are similar to what has been reported with $\mathrm{CuO}-\mathrm{SnO}_{2}[13,14]$ and

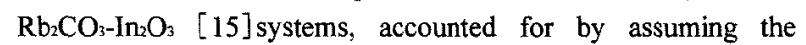
formation of a p-n junction between p-type ( $\mathrm{CuO})$ and n-type $\left(\mathrm{SnO}_{2}\right)$ or p-type $\left(\mathrm{Rb}_{2} \mathrm{CO}_{3}\right)$ and n-type $\left(\mathrm{In}_{2} \mathrm{O}_{3}\right)$.

The present result seems to confirm that $p-n$ junction is formed at the interface between $\mathrm{Mn}_{2} \mathrm{O}_{3}$ ( $\mathrm{p}$ type) and $\mathrm{SnO}_{2}$ ( $\mathrm{n}$ type) in $\mathrm{Mn}_{2} \mathrm{O}_{3}-\mathrm{SnO}_{2}$ system. That is, in air the electron transfer from $\mathrm{SnO}_{2}$ (work function; $4.69 \mathrm{eV}$ ) into $\mathrm{Mn}_{2} \mathrm{O}_{3}$ (electronic potential of $\left.\mathrm{Mn}^{3+} / \mathrm{Mn}^{2+} ; 5.95 \mathrm{eV}\right)$ may occur at the $\mathrm{SnO}_{2}-\mathrm{Mn}_{2} \mathrm{O}_{3}$ interface. This electron transfer causes the upward band bending of $\mathrm{SnO}_{2}$ surface, resulting in an increase of the resistance of $\mathrm{SnO}_{2}$. From the charge transfer consideration, the $\mathrm{BE}$ of $\mathrm{Sn} 3 \mathrm{~d} s / 2$ and $O$ Is may shift to higher energy side due to the contact with $\mathrm{Mn}_{2} \mathrm{O}_{3}$. However, the $\mathrm{BE}$ rather shifts to lower energy side due to the upward band bending of n-type $\mathrm{SnO}_{2}$ surface. In the same way, the energy band of $\mathrm{Mn}_{2} \mathrm{O}_{3}$ will be bent in the opposite direction, resulting in an upward shift of $\mathrm{Mn} 2 \mathrm{p}_{3 / 2}$ level from the $\mathrm{Mn} 2 \mathrm{p}_{3 / 2}$ state of pure $\mathrm{Mn}_{2} \mathrm{O}_{3}$. On the other hand, in the $\mathrm{HCHO}$, the $\mathrm{Mn}_{2} \mathrm{O}_{3}$ state may change to $\mathrm{Mn}_{3} \mathrm{O}_{4}$ or $\mathrm{MnO}$ with lower work functions than $\mathrm{SnO}_{2}$. So, the electron transfer from $\mathrm{Mn}_{3} \mathrm{O}_{4}$ or $\mathrm{MnO}$ to $\mathrm{SnO}_{2}$ occurs at the interface of $\mathrm{Mn}_{2} \mathrm{O}_{3}$ and $\mathrm{SnO}_{2}$, resulting in the decrease in the resistance of $\mathrm{SnO}_{2}$. A p-n junction outline could be the following:

$\mathrm{MnO}_{2}$ or $\mathrm{Mn}_{2} \mathrm{O}_{3}$ (p) $-\mathrm{SnO}_{2}$ (n) [in air]

$\leftrightarrow \mathrm{Mn}_{3} \mathrm{O}_{4}$ or $\mathrm{MnO}(\mathrm{p})-\mathrm{SnO}_{2}(\mathrm{n}) \quad$ [in reduced gas] We note here that the higher oxide state of Mn changes easily to lower oxide state under the reduced atmosphere as follows [16]:

$\mathrm{MnO}_{2} \rightarrow \mathrm{Mn}_{2} \mathrm{O}_{3} \rightarrow \mathrm{Mn}_{3} \mathrm{O}_{4} \rightarrow \mathrm{MnO} \rightarrow \mathrm{Mn}$ As the electron affinity of $\mathrm{Mn}_{2} \mathrm{O}_{3}$ is also much stronger than that of the adsorbed oxygen, which leads to an enhancement of the gas sensitivity. As a result, the sensing properties of $\mathrm{Mn}_{2} \mathrm{O}_{3}-\mathrm{SnO}_{2}$ systems to HCHO might be extremely improved.

In addition, as we mentioned before, it seems that the chemical sensitization operated largely upon the sensitivities of these sensors to HCHO gases, too.

\section{3-5 Sensing properties of $\mathrm{SnO}_{2}$ sensors loaded with both $\mathrm{Ag}$ and $\mathrm{Mn}_{2} \mathrm{O}_{3}$}

As shown in the above sections, it is found that $\mathrm{Ag}$ and $\mathrm{MnO}_{2}$ are effective to detect the low concentration $\mathrm{HCHO}$ as additives for $\mathrm{SnO}_{2}$. In order to further increase sensitivity of $\mathrm{SnO}_{2}$ sensor, $\mathrm{SnO}_{2}$ doubly promoted by $\mathrm{Ag}$ and $\mathrm{Mn}_{2} \mathrm{O}_{3}$ was investigated.

The result of the measurement at $300{ }^{\circ} \mathrm{C}$ is shown in Fig. 12. The loading amount of $\mathrm{Ag}$ was $1 \mathrm{wt} \%$ and that of $\mathrm{Mn}_{2} \mathrm{O}_{3}$ was 5 wt\%. The $\mathrm{Ag}(1 \mathrm{wt} \%)-\mathrm{SnO}_{2}$ sensor is superior to $\mathrm{Mn}_{2} \mathrm{O}_{3}$ (5 wt\%) $-\mathrm{SnO}_{2}$ sensor as for the sensitivity to $\mathrm{HCHO}$ at $300^{\circ} \mathrm{C}$. It is found in Fig.12 that the sensitivity of $\mathrm{Ag}(1 \mathrm{wt} \%)-\mathrm{MnO}_{2}$ (5 wt $\%)-\mathrm{SnO}_{2}$ sensor is as low as additive free $\mathrm{SnO}_{2}$ sensor against expectation. It is suspected that the doubly promotion to $\mathrm{SnO}_{2}$ sensor heighten too much oxidation activity to $\mathrm{HCHO}$.

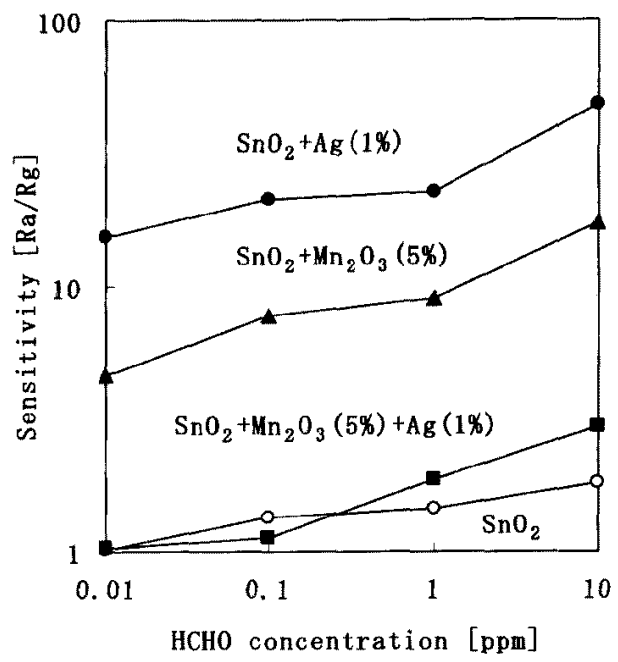

Fig.12 Sensitivities of $\mathrm{SnO}_{2}$ sensors loaded with $\mathrm{Mn}_{2} \mathrm{O}_{3}, \mathrm{Ag}$ and $\mathrm{Mn}_{2} \mathrm{O}_{3}+\mathrm{Ag}$ as a function of $\mathrm{HCHO}$ concentration at $300^{\circ} \mathrm{C}$.

\section{Conclusions}

Among various metal oxides, $\mathrm{SnO}_{2}$ is the most attractive for the detection of $\mathrm{HCHO}$. Further research has shown that both $\mathrm{Ag}$ (1 3 wt\%) and $\mathrm{Mn}_{2} \mathrm{O}_{3}(3 \sim 10 \mathrm{wt} \%)$ are excellent promoters to $\mathrm{SnO}_{2}$ for increasing the sensitivity to $\mathrm{HCHO}$. However, $\mathrm{Ag}-\mathrm{SnO}_{2}$ sensor have the very short lifetime, further investigation are necessary for this reason. It was found that $\mathrm{Mn}_{2} \mathrm{O}_{3}$ is the best promoter to $\mathrm{SnO}_{2}$ for increasing the sensitivity to $\mathrm{HCHO}$. The doubly promoted $\mathrm{Ag}(1 \mathrm{wt} \%)-\mathrm{Mn}_{2} \mathrm{O}_{3}(5 \mathrm{wt} \%)-\mathrm{SnO}_{2}$ sensor showed low sensitivity to $100 \mathrm{ppm}$ HCHO against expectation.

\section{Acknowledgments}

The authors are grateful to Mr. Masanori Hoshino (Cosel Co., Ltd.), Mr. Masayoshi Minami (Hokuriku Electric Ind. Co., Ltd.) and Miss Hiromi Yamada (Toyo Kako Co., Ltd.) for experimental assistance and discussing the results.

A part of this work was financially supported by a grant from Japan Science and Technology Corporation.

(Manuscript received September 11, 2000, revised March 22, 2001)

\section{References}

1 C.Jogetu and K.Izumi, Indoor air pollution by formaldehyde, Man \& Enviro.,23 (1997) 34-40 (in Japanese).

2 T.F.Cooke, Indoor air pollutants, Rev.Environ.Health, 9 (1991) 137-160.

3 M.Kadosaki, T.Terasawa, K.Tanino and C.Tatsuyama, 
Exploration of highly sensitive oxide semiconductor materials to indoor-air pollutants, Trans. IEE of Japan, 119-E,7 (1999) 383-389 (in Japanese).

4 N.Yamazoe, New approaches for improving semiconductor gas sensors, Sensors and Actuators B, 5 ( 1991) 7-19.

5 Y.Shimizu and M.Egashira, Basic aspects and challenges of semiconductor gas sensors, MRS BULLETIN, June (1999) 18-24.

6 Y.Takano, Y.Miya, Y.Tachiyama, Y.Simizu and M. Egashira, Improvement in Trimethylamine Sensitivity of $\mathrm{In}_{2} \mathrm{O}_{3}$ and $\mathrm{Cr}_{2} \mathrm{O}_{3}$ Sensors by Valency Control, Denki Kagaku, 58 (1990) 1162-1168.

7 N.Yamazoe, Y.Kurokawa and T.Seiyama, Effect of additives on semiconductor gas sensors, Sensors and Actuators, 4 (1983) 283-289.

8 S.Matsushima, Y.Teraoka, N.Miura and N.Yamazoe, Electronic Interaction between Metal Additives and Tin Dioxide-Based Gas Sensors, Jpn.J.Appl.Phys., 27 ( 1988) 1798-1802.

9 N.Butta, L.Cinquegrani, E.Mugno, A.Tagliente and S.Pizzini, A family of tin oxide-based sensors with improved selectivity to methane, Sensors and Actuators B, 6(1992) 253-256.

10 N.Yamazoe, 81th CATSJ Meeting Abstracts:No.1B02, 40 (1998) 110-111.

11 Chao-Nan Xu and J.Tamaki, N.Miura and N.Yamazoe, Nature of sensitivity promotion in Pd-loaded $\mathrm{SnO}_{2}$ gas sensor, J.Electrochem.Soc., 143 ( 1996) L148-L150.

12 T.Maekawa, J.Tamaki, N.Miura and N.Yamazoe, Gold loaded tungsten oxide sensor for detection of air, Chem. lett., (1992) 639-642.

13 J.Tamaki, T.Maekawa, N.Miura and N.Yamazoe, $\mathrm{CuO}_{-} \mathrm{SnO}_{2}$ element for highly sensitive and selective detection of $\mathrm{H}_{2} \mathrm{~S}$, Sensors and Actuators B, 9 (1992) 197-203.

14 J.Tamaki, N.Miura and N.Yamazoe, Formation and role of p-n contacts in $\mathrm{CuO}_{-} \mathrm{SnO}_{2}$ based $\mathrm{H}_{2} \mathrm{~S}$ sensor, Journal of the Surface Society of Japan, 17 (1996) 469-474 (in Japanese).

15 H.Yamaura, T.Jinkawa, J.Tamaki, K.Moriya, N.Mura and N.Yamazoe, Indium oxide-based gas sensor for selective detection of CO, Sensors and Actuators B, 35(1996) 325-332.

16 T.Seiyama, Metal oxide and the catalysis. Japan:Kodansha (1978) 5-6, 179-184. (in Japanese).
Masahiro Kadosaki(Member) was born in 1951. He

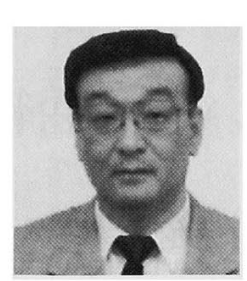
received the B.S, M.S and Ph.D. degrees from Toyama University in 1975, 1977 and 2001, respectively In 1983, he joined Toyama Industrial Technology Center. He is currently engaged in the research and development of oxide semiconductor gas sensors

Shigekazu Yamazaki (Non-Member) was born in 1958. He

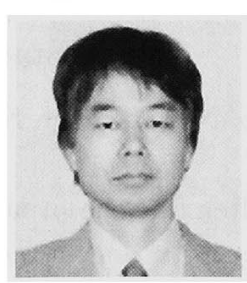
received the B.S, M.S and Ph.D. degrees from Kyoto University in 1981, 1984 and 1987, respectively. In 1987, he joined Toyama Industrial Technology Center. He is currently engaged in the research and development of catalyst for oxidation of organic compound.

Satoshi Fujiki (Member) was born in 1950. He received the

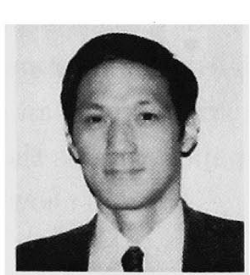
B.S and Ph.D. degrees from Toyama University in 1973 and 1998. In 1975, he joined Toyama Industrial Technology Center. He is currently engaged in research and development of reliability of electronic parts and micromachining.

Katsumi Tanino (Member) was born in 1946. He received

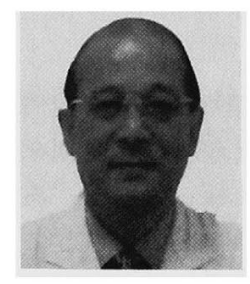
the B.S degrees from Kanazawa University in 1969. In 1969, he joined Toyama Industrial Technology Center. He received the Consulting Engineer from Japan in 1983 and Ph.D. from Tokyo Metropolitan University in 1985 . He has been engaged in research and development of organic electronic material

Chiei Tatsuyama(Non-Member) was born in 1943. He received his Ph.D. degree from Osaka University in 1972. He joined Toyama University in 1972 and he is now a professor at Dpt.of Electrical and electronic system engineering, Toyama University. His research interests are Molecular Beam Epitaxy, Superlattice, surface science and interface formations between hetero semiconductors and semiconductors. 